\title{
STATE FAIR LABOR STANDARDS LEGISLATION
}

\author{
LOUISE STITT*
}

Since Congress passed the Fair Labor Standards Act of $193^{8}$, the title of that Act has come to be used to designate a comprehensive type of labor law intended to regulate a variety of industrial conditions that generally in the past have been controlled by specific laws, such as minimum-wage laws, hour laws, and child-labor laws. The National Recovery Administration was the inspiration of the Fair Labor Standards Act. Ever since the United States Supreme Court decided that the NRA violated principles of the Constitution, proponents of federal labor legislation have anticipated the day when the Congress would find a way of providing wage and hour protection for workers in interstate commerce that was legal and more satisfactory than that lost with the passing of the National Industrial Recovery Act. The Fair Labor Standards Act regulates not only wages and hours but child labor, and it has been interpreted by the Administrator to apply to industrial home work.

The first real state fair labor standards acts were passed 26 years ago in I9r3 by California, Oregon, and Washington. No one in those days thought of calling these laws by the title that has since become popular. They were known then and still are known as minimum-wage laws for women and minors. Under them, nevertheless, administrators were given the authority not only to fix minimum wages but to establish "maximum hours of work consistent with the health and welfare of women and minors" and "standard conditions of labor demanded by" their well-being." The purpose of these early laws was to protect the health and morals of industrial women and minors by regulating not only their wages and hours but the sanitary and safety conditions of the places in which they were employed. Though they do not prohibit harmful child labor nor establish statutory minimum-wage rates, as does the Fair Labor Standards Act, the authority given the administrator to require healthful physical working conditions exceeds that of the Federal Act. Today nine states ${ }^{2}$ have this type of law for women and minors.

State fair labor standards laws modeled after the Federal law do not exist. Up to

* B.A., Igro, M.A., x925, Ohio State University; attended New York School of Social Work, Columbia University, also University of Wisconsin and University of Pennsylvania. Director, Division of Minimum Wage, Women's Bureau, United States Department of Labor. Formerly Assistant Professor of Economics, Ohio State University. Author, Benefits of Minimum Wage Legislation for Women (U. S. Dept. of Labor, I937). Contributor to periodicals on the subject of minimum wage legislation.

${ }^{1}$ CaLIF. Gen. Laws (Deering, I93I) Act $3613, \$ 6$.

${ }^{2}$ California, Colorado, Kansas, Louisiana, North Dakota, Oklahoma, Oregon, Utah, and Washington. 
the present, no state has passed such legislation. Twenty-five states, ${ }^{3}$ Alaska, the District of Columbia, and Puerto Rico regulate the wages of women through state minimum-wage laws; all states but Alabama, Florida, Iowa, and West Virginia regulate the hours that women may work, and many regulate the hours of men in certain occupations. Laws protecting children against too early or harmful employment have been passed by all the states, and $18^{4}$ control industrial home work by law. But so far no state regulates all these labor conditions by means of a single piece of legislation similar in pattern to the Federal Act.

Though it was estimated upon the passage of the Fair Labor Standards Act that approximately In,000,000 workers would be covered by the provisions of the new law, it was realized that probably more than twice that number would remain unprotected. Workers employed in intrastate commerce are not affected by the Federal law. Few state hour laws and only one minimum-wage law ${ }^{5}$ apply to men, and many states have not yet passed minimum-wage laws even for women.

The answer to this problem of the unprotected worker seemed to many friends of labor legislation to be the passage by the states of laws similar to the Federal Act that would apply to men and women employed in intrastate industries. It was remembered that in the days of the National Recovery Administration 23 states followed the example of the Federal Government by passing state recovery acts. Public reaction to the passage of the Fair Labor Standards Act of 1938 was so favorable that many persons believed that the states would be quick to supplement the federal law with "little fair labor standards acts." The legislatures of 44 states were to be in regular session during the early months of 1939 , thus affording a favorable opportunity for the introduction of such bills in a large number of states.

The Secretary of Labor therefore appointed a committee of state labor commissioners and representatives of the American Federation of Labor and of the Congress of Industrial Organizations to draft a State bill, which would meet the needs of the states and appropriately supplement the Federal Act. To avoid confusion with the Federal Act, and because the title, Fair Labor Standards, describes less accurately the state bill as drawn than it does the Federal law, the new draft became known offcially as "Suggested Language for a State Wage and Hour Bill." The bill was approved in November $x 93^{8}$ by the National Conference on Labor Legislation, called annually by the Secretary of Labor, and became the basis for the similar bills adopted

\footnotetext{
${ }^{3}$ Arizona, Arkansas, California, Colorado, Connecticut, Illinois, Kansas, Kentucky, Louisiana, Massachusetts, Minnesota, Nevada, New Hampshire, New Jersey, New York, North Dakota, Ohio, Oklahoma, Oregon, Pennsylvania, Rhode Island, South Dakota, Utah, Washington, and Wisconsin. On April 2I, I939, a bill that applies only to women and minors employed in the fish-packing industry was approved in Maine. The Alaska law was approved March 9, 1939.

- California, Connecticut, Illinois, Indiana, Maryland, Massachusetts, Michigan, Missouri, New Jersey, New York, Ohio, Oregon, Pennsylvania, Rhode Island, Tennessee, Texas, West Virginia, and Wisconsin.

The Oklahoma minimum-wage law is the only state minimum-wage law that covers men as well as women. The Supreme Court of that State, however, ruled on March 21, 1939, that the application of the law to men is unconstitutional, not because the principle is unsound but because of a faulty title. Associated Industries of Okla. v. Industrial Welfare Commission, 90 P. (2d) 899.

- The bill is set forth in Appendix II of the Proceedings of the Fifth National Conference on Labor Legislation, also on pp. $801 \mathrm{I}-80 \times 8$ of the C. C. H. Labor Law Service.
} 
somewhat later by the American Federation of Labor and the Congress of Industrial Organizations.

In its broad outlines the State wage and hour bill follows the pattern of the Federal Fair Labor Standards Act. Both provide for statutory rates covering men as well as women, and for the appointment by the administrator of official bodies, known under the Federal Act as industry committees and in the State bill (Section 5) as wage boards, to recommend for specific occupations wages higher than those established by statute. There was much discussion by the Secretary's committee of the desirability of including in the State draft the "flat-rate" provision. This type of state legislation had always been frowned upon by labor-legislation experts in the past. It was known that it was not the original intention to include this provision in the Federal Act, but that its inclusion was the result of compromise. In the three states having so-called flat-rate laws, they have for the most part proved very ineffective. For obvious reasons wages fixed by a legislature are almost bound to be low and inflexible, and the initial expense of setting up an adequate inspectorate to police an entire state covered at one time by a general wage law has proved so overwhelming that little or no enforcing has been done and the laws have tended to become dead letters. However, as the main purpose of the new State wage and hour legislation was to supplement the Federal law, and as the statutory rate has the advantage of guaranteeing complete coverage quickly, the committee decided that in so fundamental a matter as this the two laws should correspond.

So the State bill (Sections 3 and 4), like the Federal Act, provides for statutory rates that increase automatically over a period of seven years, and for progressively shorter weekly hours during a two-year period. Under the Federal law industry committees may not recommend wages higher than 40 cents an hour, but the State bill (Section 6(c)) places no such limitation on state wage boards and the amounts that they may propose. Neither the Federal Act nor the State draft actually limits the number of hours an employee may work. For the curtailment of long hours and the spread of employment both depend on the requirement that time worked in excess of the weekly hours stipulated in the statute shall be paid for at one and onehalf times the employees' regular wage rates. The Federal Act does not require overtime payment for daily hours, but the State draft would require employers to pay one and one-half times the regular rate for hours worked in excess of eight in any one day.

The Federal Fair Labor Standards Act and the State wage and hour law come under very different governmental powers; therefore, the declared policy of the State bill and the Federal Act and the principles laid down in each to guide the administrators in determining minimum wages are quite different. The Congress found its justification for regulating wages and hours in the Commerce Clause of the Federal Constitution. The policy of the Federal Act is to eliminate as rapidly as possible labor conditions detrimental to the health, efficiency, and general well-being of the workers because these conditions constitute an unfair method of competition, 
lead to labor disputes that obstruct the free flow of goods in commerce, and cause commerce to be used to spread such labor conditions among the workers of the states. Industry committees are authorized to recommend to the administrator the highest minimum-wage rates (not to exceed 40 cents an hour), compatible with economic and competitive conditions, which will not substantially curtail employment in an industry. The State bill, coming as it does under the police power of the States, attacks the problem much more directly, and has as its declared policy the protection of the general welfare and of the health, efficiency, and well-being of workers through the establishment of minimum-wage and maximum-hour standards (Section 1). Wage boards are required when recommending minimum wages to take into account " $(\mathrm{I})$ cost of living, (2) the wages established in the State for work of like or comparable character by collective labor agreements negotiated between employers and employees by representatives of their own choosing, and (3) the wages paid in the State for work of like or comparable character by employers who voluntarily maintain reasonable minimum-wage standards" (Section 6(c)).

The exemptions under the State draft are far less numerous than those authorized by the Federal Act. The State bill exempts from the wage and hour provisions persons "employed ( $\mathrm{I}$ ) in a bona-fide executive or professional capacity (as such terms are defined and delimited by regulations of the commissioner of labor), (2) in agriculture, and (3) in domestic service in a private home" (Section 2(d)). The payment of higher overtime rates is not required in cases of extraordinary emergencies, such as those resulting directly from fire, flood, or storm (Section 4 (b)).

The final draft of the Fair Labor Standards Act shows the influence of special groups that for various reasons sought and secured exemption of their employees from some or all of the provisions of the Act. In addition to the exclusion from the wage and hour regulation of employees in bona-fide executive, administrative, professional, and local retailing capacities, or in retail or service establishments the greater part of whose selling or servicing is in intrastate commerce, or as outside salesmen, or in agriculture, seamen, workers engaged in any kind of employment connected with aquatic forms of animal and vegetable life, employees of certain types of small-town newspapers, individuals engaged in the processing of agricultural or horticultural commodities or the making of dairy products if carried on in the area of production, all are exempt, as are local trolley, motor bus, and interurban electricrailway employees and employees of carriers by air who are subject to provisions of the Railway Labor Act.

The hour regulation does not apply to workers engaged in the first processing of milk into dairy products, in the ginning and processing of cotton, or in the processing of cottonseed, or in the processing of sugar beets, sugar-beet molasses, sugar cane, or maple sap into sugar (but not refined sugar) or into syrup. Employees covered by certain sections of the Interstate Commerce Act and the Motor Carrier Act of 1935 also are exempt from the hour provision of the Fair Labor Standards Act. In seasonal industries for a period of $\mathrm{x}_{4}$ weeks the overtime rate need not be paid until the work- 
week exceeds 56 hours or the workday 12 hours. This same provision, requiring overtime only after $5^{6}$ hours a week or 12 a day, applies to employees covered by bonafide collective bargaining agreements which provide that no worker shall be employed more than r,000 hours during any period of 26 consecutive weeks, nor more than 2,000 hours during any period of 52 consecutive weeks.

The State Wage and Hour Bill, unlike the Fair Labor Standards Act, does not provide for the regulation of child labor. Experts in the field of child labor believed it would be preferable to encourage each state to amend its existing child-labor law to equal the standards set by the Federal law than to include such provisions in the general State bill. There is no reference in the Federal Act to industrial home work. The Administrator has ruled, ${ }^{7}$ however, that workers on goods intended for interstate commerce, even though they are employed in their own homes, must be paid the minimum wages applicable to all workers covered by the law. The law does not classify workers on the basis of the places in which they work. The State Wage and Hour Bill is much more definite than the Federal in its provisions concerning industrial home work. The labor commissioner is given the power to issue regulations and orders necessary to carry out the provisions of the law. Such regulations may include the restriction or prohibition of industrial home work.

Probably because trade unionists sat on the drafting committee, the State bill carries a section which provides that nothing in the act shall be deemed to interfere with the right of employees to bargain collectively through representatives of their own choosing for wages higher than those established under the act or for hours that are shorter.

Both the Federal Act and the State bill provide against wage discrimination on the basis of age or sex.

The Federal Act permits the administrator of the law to use the services and the employees of state labor departments, provided these departments agree to cooperate, for the purpose of enforcing the Fair Labor Standards Act, and to reimburse these state agencies for their services. Because special legislation is required in some states to permit state departments to accept federal funds, a section ( $\mathrm{r}_{3}$ ) was written into the State bill authorizing state agencies to assist and cooperate with the Wage and Hour Division of the United States Department of Labor in the enforcement of the Fair Labor Standards Act within the state, and to be reimbursed by the Federal Department for the cost of such services.

The State wage and hour bill adopted later by the Congress of Industrial Organizations is practically like that drafted by the Secretary's committee. The only real difference between the two bills is that the CIO draft does not exempt professional nor domestic workers from the provisions of the law. Though the American Federation of Labor's draft does not follow so closely the committee's language for a State wage and hour bill as does that of the CIO, the provisions are almost identical. While the two other bills do not mention employees of the State, the AFL bill

\footnotetext{
${ }^{7}$ Wage and Hour Division, Release, April 13, 1939; see $\$ 6$ of the Act.
} 
specifically exempts such workers. The AFL bill does not release employers from the obligation of paying the time and one-half overtime rates even during emergencies, as do the other drafts. Wage-board members are limited to nine by the AFL bill, while no limitation is placed on the number of board members in the other bills. The provision of the Federal Act limiting the minimum wage that can be established through wage-board procedure to 40 cents an hour is followed in the AFL draft. No wage board may recommend less than 30 cents an hour. The American Federation of Labor takes the position that wages above 40 cents should be set through collective bargaining and not by law.

Copies of these three drafts were distributed widely throughout the states by the two national labor organizations and by the United States Department of Labor. The purpose was, of course, to get these bills into the hands of state legislators who would sponsor them in their own legislatures. It was hoped that the bills would be carefully adapted to local conditions, but that the general structure would be maintained, so that the conformity with the Federal Act that had been the object of the drafting committee could be assured in state legislation. Forty-two ${ }^{8}$ wage and hour bills of some type were introduced into $29^{\circ}$ of the 44 state legislatures that were in regular session during the early months of 1939. In some states three or four bills were introduced, each differing from the others in some major or minor respect. If only those bills are included in the count that may fairly be called fair labor standards bills, inasmuch as they follow the federal plan of regulating wages through the device of combining statutory rates and wage-board procedure, and hours through overtime rates, 36 bills $^{10}$ were introduced into the legislatures of 26 states. ${ }^{11}$

Eighteen ${ }^{12}$ of these 36 bills followed for the most part the draft approved by the Fifth National Conference on Labor Legislation, five others (Maryland, Massachusetts, Michigan, New York, and West Virginia) included professional and domestic workers as recommended by the Congress of Industrial Organizations, and eight ${ }^{13}$ were modeled after the American Federation of Labor bill. Three bills patterned directly from the Federal Fair Labor Standards Act were introduced into two state legislatures. ${ }^{14}$ In California two bills were introduced that would amend the present minimum-wage law for women by extending it to men and by introducing the

\footnotetext{
${ }^{8}$ The writer cannot be absolutely certain of the accuracy of her statement concerning the number of wage and hour bills introduced in the State legislatures this session. She has had access to the bills furnished by the Commerce Clearing House, and there are 42 of these at present. This count does not include companion bills (the same bill introduced into both houses of the legislature) nor bills later substituted for the original bill.

- Arizona, California, Colorado, Connccticut, Delaware, Idaho, Illinois, Indiana, Kansas, Maine, Maryland, Massachusetts, Michigan, Missouri, Montana, New Hampshire, New Jersey, New Mexico, New York, North Carolina, Ohio, Rhode Island, South Carolina, Tennessee, Utah, Washington, West Virginia, Wisconsin, and Wyoming.

${ }^{30}$ See note 8 supra.

${ }^{11}$ Of the 29 states in which wage and hour bills were introduced, Kansas, North Carolina, and South Carolina are the 3 in which bills that conform with the definition of a fair labor standards bill as used in this paragraph were not introduced.

${ }^{22}$ Arizona (2 bills), California, Colorado, Idaho, Indiana, Maine, Massachusetts (2 bills), Montana, New Hampshire, New Jersey, New Mexico, Tennessee, Utah, Washington, Wisconsin, and Wyoming.

${ }^{13}$ Connecticut, Delaware, Illinois, Maryland, Massachusetts, Missouri, Ohio, and Rhode Island.

it Connecticut (2 bills) and Missouri.
} 
flat-rate provision. In addition to these 36 bills, six that would regulate hours and establish minimum wages by statute with no provision for modification of the rates through wage-board recommendations were introduced into five ${ }^{15}$ state legislatures.

It is impossible to make a hard and fast classification of these bills, because in very few cases was any one of the model drafts accepted without some modification by the legislators who became sponsors of the bills. In some states joint committees representing labor, employer, and public organizations carefully scrutinized the proposed bills in light of their local conditions and agreed upon important changes that were incorporated in the bills as finally introduced. However, the grouping used above gives a fairly satisfactory idea of the type of the 42 wage and hour bills introduced into the I939 State legislatures.

It is interesting to note to what extent these bills followed the standards set by the Federal Fair Labor Standards Act or suggested in the State wage and hour drafts. Seventeen of the 42 bills provide for higher statutory minimum wages than those to be found in the flat-rate provisions of the Federal Fair Labor Standards Act. Eight of the II States ${ }^{16}$ in which bills have been introduced providing for higher rates are states that already had minimum-wage laws for women. This fact may explain in part the willingness of the legislators to sponsor bills with the higher rates, because the wages established under state minimum-wage laws generally are higher than the statutory rates provided by the Federal Fair Labor Standards Act and repeated in 22 of the state wage and hour bills. Ninety percent of the minimum rates set by the states under minimum-wage laws for women exceed 25 cents, which is the minimum for the first year under the Fair Labor Standards Act, and 30 cents, the federal rate for the next six years, is equaled or exceeded by 75 per cent of the state rates for women.

Though none of the State wage and hour bills provides for a minimum rate of less than 25 cents an hour, three ${ }^{17}$ bills would establish wage standards lower than those permitted by the Federal Act. All these bills are so-called flat-rate bills, which make no provision for increases in rates through wage-board procedure. The South Carolina bill and one of the two West Virginia bills provide for a flat hourly rate of 25 cents without the escalator clause of the Federal Act that authorizes automatic increases above 25 cents over a period of years. The North Carolina bill, like the Fair Labor Standards Act, provides for automatic increases from 25 to 40 cents during a seven-year period, but it excepts employees of mercantile and service establishments from these increases. For these workers a flat 25-cent hourly rate is provided.

In only three southern States, North Carolina, South Carolina, and Tennessee, was any type of wage and hour bill introduced during this year's legislative session. Two of the bills introduced in these states are described in the foregoing paragraph. The

${ }^{16}$ Kansas, Montana, North Carolina ( 2 bills), South Carolina, and West Virginia.

${ }^{16}$ Arizona, California, Connecticut, Massachusetts, New Jersey, New York, Utah, and Washington have minimum-wage laws; Michigan and Montana have not. Maine has passed a law for one industry only.

${ }^{17}$ North Carolina, South Carolina, and West Virginia. The New Mexico bill was amended before it was finally killed to provide for a flat rate of 25 cents an hour and no wage boards. 
Tennessee bill follows fairly consistently the suggested language for a State wage and hour bill. The second North Carolina draft is a flat-rate bill that makes no provision for wage boards but does carry the same rates as are found in the escalator clause of the Federal Act.

The provision of the three standard State drafts concerning daily hours and the basic weeks provided for in the Fair Labor Standards Act were followed in practically three-fourths of the State wage and hour bills; that is, these bills required that overtime rates must be paid for daily hours in excess of eight, and for weekly hours in excess of 44 during the first year the law is in effect, in excess of 42 hours during the second year, and in excess of 40 hours thereafter. Only four bills, two of which follow the Federal Fair Labor Standards Act, fail to place a penalty on long daily hours. Three bills would permit 48 hours of work during any one week before requiring that higher overtime rates be paid. The principle of regulating hours, both daily and weekly, through the payment of higher rates for overtime is followed in the remaining five bills, but in each the length of the basic week for which regular hourly rates are to be paid varies from the provisions of the Federal Act.

The device of controlling industrial home work through the mechanism of the wage and hour law apparently appealed to the authors of the State bills, because 35 of the 42 bills give the commissioner of labor the authority to restrict or prohibit industrial home work. As to agricultural workers, only a Maryland bill and a proposed amendment to the present California minimum-wage law for women have departed from the three standard draft bills by including agricultural workers. Eight $^{18}$ bills include domestic workers. The New York bill excludes this class of workers from the statutory rates and the overtime regulations of the bill, but provides that a wage board may be appointed to recommend appropriate minimum wages and maximum hours for domestic workers. All but three (one in Arizona and two in California) of the remaining bills exempt such employees from the hour provisions altogether or permit 60 hours of work before the overtime rates must be paid.

The great majority of the wage and hour bills introduced in legislatures in the past winter confined exemptions to those classes of employees suggested in the committee's bill, namely, executives, professional workers, and persons employed in agriculture and domestic service in private homes. One wonders, however, if this would have continued to be the case if more legislatures had given these bills more serious consideration. Comparatively few bills reached the stage of debate on the floor of either house of the legislature, and even fewer demanded sufficient attention to lead to substantial amendment. An analysis of the amendments made to a few of the bills, however, throws some light on the kind of exemptions that might have been demanded if more bills had been seriously considered for passage. One example is that of a bill that was amended to exclude any employee covered by the Federal Fair Labor Standards Act. Amendments excluding employers of less than a certain number of employees were made in two cases. The exemption of outside salesmen,

${ }^{28}$ Arizona, California ( 2 bills), Maryland, Massachusetts, Michigan, New York, and West Virginia. 
of employees covered by certain provisions of the Interstate Commerce Act and Railway Labor Act, workers engaged in the processing of certain agricultural products, and employees of small newspapers are types of amendments obviously suggested by the provisions of the Fair Labor Standards Act. Exemptions of this kind are much more likely to be sought under statutes in which specific rates are set than under laws that establish minimum wages only through the wage-board procedure. An examination of state minimum-wage laws of the latter type will reveal that few workers are exempted except domestic workers and laborers on the farm.

An amendment was suggested to the authors of wage and hour bills introduced in states already having minimum-wage laws for women by the Women's Bureau of the U.S. Department of Labor and by others interested in securing and maintaining living wages for working women. The purpose of this amendment was to guarantee the nonrepeal of existing minimum-wage laws for women and the validity of wage orders issued under them. The reason for concern about this matter was that the courts have not yet ruled on the constitutionality of the Federal Fair Labor Standards Act and other laws modeled after it; in fact, the United States Supreme Court has not ruled on the constitutionality of any type of minimum-wage legislation for men. Persons interested in the welfare of women were not willing to see laws that had been upheld by the Supreme Court replaced by others on which there had as yet been no ruling. The hope was that until the courts had ruled on the new type of legislation, the two laws could stand on the statute books together.

The introduction of these 42 State wage and hour bills in the legislatures of 29 states doubtless has had important educational results. The public knows much more about this type of legislation than it would have known if these bills had not been introduced. But so far as additions to state labor legislation of wage and hour laws of the type discussed in this paper are concerned, the net result of this year's legislative sessions is exactly zero. Only one bill has been approved by even one house of any state legislature. That is the New Jersey bill which was passed by the Assembly June 2I, 1939. Thirty have died either through adjournment or by action taken by the legislature before adjournment. One has been killed by a legislature that is still in session. There is a possibility that some bills may yet be passed by the seven legislatures still in session in which bills have been introduced but have not yet been acted on. However, the time is getting short, and the prospects of an abundant harvest of State fair labor standards acts is gradually waning.

It is interesting to speculate on the reasons for the failure of any of these bills to pass. The comment most frequently heard in legislative chambers is "We want to give the Federal law a chance to work. If its operation is successful during the next two years, we will then be ready to consider a State bill." Some less well informed legislators seem to be under the impression that the existence of the Federal Act removes the necessity for state legislation. Any kind of labor legislation is difficult to secure without strong labor support. Wage and hour legislation, if passed, would benefit most the unorganized workers. This group is likely to comprise our least 
articulate citizens and cannot be depended on to press for any kind of legislation. The American Federation of Labor has never really accepted the philosophy of minimum-wage legislation. Its opinion has not changed though it adopted an official State wage and hour bill. In most states where this bill has been introduced the organization has done little to influence its passage; in fact, some State Federations of Labor have recommended the postponement of passage until an opportunity for further study may be had. The Congress of Industrial Organizations seems to be genuinely in favor of this type of state legislation, but in most states its influence with the legislators has not been sufficient to secure the passage of these bills.

It may be true, as some state legislators have remarked, that two years' experience under the Federal Fair Labor Standards Act may suggest many practical changes that should be made in the State draft. By the end of the next two years the courts may have placed their stamp of approval on this new type of legislation, thus removing the uncertainty concerning its constitutionality that has been one argument against immediate passage. The conservative complexion of this year's state legislatures may be considerably modified before the r94I sessions. Or events beyond the control of either state or federal legislature may remove such questions temporarily from the public interest. However that may be, today in the United States of America there is no State fair labor standards law modeled after the Federal Fair Labor Standards Act of 1938 . 